\title{
English for Employability: A Case Study of the English Language Training Needs Analysis for Engineering Students in India
}

\author{
A. Clement ${ }^{1} \&$ T. Murugavel ${ }^{1,2}$ \\ ${ }^{1}$ School of Enginnering, Saveetha University, Chennai, India \\ ${ }^{2}$ Sri Venkateshwara College of Engineering, Chennai, India \\ Correspondence: A. Clement, ALBA Flats, 78.4, II Main Street (North), Sadasivam Nagar, Madipakkam, \\ Chennai, India. Tel: 919-884-806-118. E-mail: aloyclement@gmail.com
}

\author{
Received: November 5, 2014 Accepted: December 7, 2014 Online Published: January 20, 2015 \\ doi:10.5539/elt.v8n2p116 URL: http://dx.doi.org/10.5539/elt.v8n2p116
}

\begin{abstract}
This article examines the effectiveness of English language courses offered in the engineering colleges in India. Many engineering graduates in India are found to be unemployable due to their poor communication skills and lack of confidence. There have been a lot of research papers that have reiterated the importance of improving engineering graduates' employability skills; however, the problem of poor communication skills grows unabated in India. This study is mainly conducted to understand the reality in English classrooms of engineering colleges to unravel the mystery behind the poor performance of many engineering graduates in India. It has been identified that many third year students are still lacking confidence to face their campus placements that are to take place in their final year of study. Moreover, it has been found that the methodologies of faculty members need to be enhanced as large number of students want more interactive sessions to improve their language skills. The survey results have shown evidence of gap between the English professors' methodology and engineering students' confidence levels and also accentuate the importance of suitable training programs for required for engineering students.
\end{abstract}

Keywords: English for engineers, CLT, ESP, employability, communication skills, teaching methodologies, needs analysis

\section{Introduction}

English has been an integral part of Indian curriculum for decades and it plays a major role in finding job placements in renowned organizations. India and English language have become inseparable due to British colonization and English has become the second language to many educated Indians. Moreover, it has become a connecting language for educated Indians as people speak different languages in each state of the country. In 1700s, English became the official language of administration and many educated Indians learnt the language as it helped them to go up the career ladder. The influence of English grew unabated even after the British left India in 1947. Today, English language plays a vital role in higher education, media and administration of private and government organizations. English has become a powerful agent for change in India (Graddol, 2010).

The number of engineering colleges in India has increased exponentially in the last decade. According to the news article in India Today, there are 3393 colleges in India (India Today, 2013) and hundreds of thousands of engineering students graduate every year. This increase in the number of engineering graduates has caused serious turbulence in the job market and the employability of graduates has become the core issue in educational and industry sectors. Today's job market in India is quite demanding and challenging that the engineering graduates are expected to possess employable qualities when they appear for job interviews. Candidates are expected to voice their ideas in English without any ambiguity and fear. English communication skill is one of the most important employability requirements in modern India. Unfortunately, more number of engineering graduates in India finds it a taunting task to speak or write in English with fluency and accuracy.

English is taught in the first two semesters of engineering study in most of the government and private universities in India. The primary objective of this course is to improve the communication skills of students in all the four skills (LSRW). These courses are taught by professors with M.Phil or Ph.D qualifications. Most of these professors have completed their master's degree in English literature. ESP or CLT are not familiar terms 
among many English professors in India as most of them were not trained in ELT methodologies. Research in ELT methodologies is a new phenomenon in India as British Council has introduced professional development programs for English teachers working in schools (Padwad \& Dixit, 2011). Though there have been many conferences and workshops on new methodologies of language teaching, the reality of classrooms present a different picture due to various reasons:

1) Lack of training for English professors.

2) Students of different levels in the same class.

3) Number of students in each class (60 per class).

4) Lack of time to complete the prescribed syllabus.

5) More importance on written exams (traditional method in India).

6) Pressure on teachers to produce high pass percentage in final exams.

7) Lack of quality text books.

8) Use of workbooks that compile the exercises from previous university question papers.

9) Lack of support from college managements.

10) English being treated as yet another subject to study.

11) Irrelevant syllabus design.

12) Lack of relevant methodologies (P’Ryan, 2008).

The traditional methods of teaching are still followed by many English professors in engineering colleges. In most cases, English professors are under pressure to complete the recommended syllabus within three months and assessments are done by written exams at the end of the semester. This method of assessment steals the luster of learning a language with motivation and makes the sessions bland and futile. As a result, many engineering students do not make much progress in learning new skills that are required to make them employable. In many colleges, a paper called 'Communication Skills' has been introduced in the third year and students are made to listen to English conversations in communication labs. Students are trained to participate in group discussions to share their ideas. In spite of these efforts, lack of ability to communicate in English language has been an incessant challenge for many engineering students in India.

\section{The Issue of Unemployability}

According to a study conducted by 'Aspiring Minds' an education, employment and training assessment company, $25 \%$ of the engineering students doesn't have English comprehension skills. 55000 engineering graduates were examined based on a Aspiring Minds Computer Aptitude Test (ACMAT) in 2011 and the key findings indicated that more than $25 \%$ engineers do not possess the English comprehension skills to understand engineering school curriculum. The findings also state that only $57 \%$ engineers can write grammatically correct sentences in English. It was also found that around $42 \%-45 \%$ engineers display capabilities in English required for the knowledge-based industry and lastly not more than $27 \%$ engineers show capabilities in business English (Seetha, 2012).

In most of the surveys conducted among the employers, communication skill in English has been identified as one of the prime setbacks of engineering graduates of India in finding jobs. Azam, Chin, and Prakash (2010) found that that English communication skills augment the hourly wages of men by an enormous $34 \%$. A superior knowledge of English is the need of the hour as Indian economic activities are internationalized. Thus, the high ranking of interaction in English could be also accorded to the fact that there has been a rising requirement for Indian engineers in the software and information technology-enabled service (ITES) segments that are offering services in English to clients across the United Kingdom and the United States (Ferrari \& Dhingra, 2009).

In response to the lack of knowledge regarding the English skills needed by Indian engineering graduates for job placements, this study investigates of the suitability of the English courses and the methodology adapted by English faculty during the first year of engineering course in colleges and private universities in India. The prime objective of these courses is to improve the communication skills of students so that they will be able to face their job interviews and to participate in group discussion which is part of the recruitment process in India.

The role of English in business world is well-known and to handle international business deals English language skills play a vital role (M. Pandey \& P. Pandey, 2014). Poor language skills will create a lot of confusion in business deals and hence companies in India choose candidates with higher level of proficiency in English. Besides this, majority of the scientific papers or magazines across the globe are written in English (P'Rayan, 
2007). To become competent engineering graduates, students in India need to learn skills pertaining to job interviews, presentations, group interaction, and telephone and teleconference communication. According to Riemer (2002), a global engineer must cross national and cultural borders and only English language skills can help the engineer to break those boundaries.

The big question that is still not answered is whether engineering students in India are trained to upgrade their language skills that are relevant to workplace responsibilities and whether proper methodologies are followed in English sessions. This article addresses the following research questions:

1) Has the English course equipped the students in language skills?

2) Do the English professors train the students to face the challenges of industry?

3) How confident are the engineering students to face job interview sessions and group discussions?

4) Are the students happy that they are aptly trained for employability?

\section{Methodology}

In order to recognize the aptness of English courses offered to first year engineering students, survey and semi-structured interviews were conducted. The process of this study comprises survey questionnaire, interviews, class observation and written comments of students.

\subsection{Participants, Location, and Instruments Review}

This study took place on-site at Saveetha University in Chennai, India. The participants of this study were from different engineering colleges who came to attend a technical workshop in Saveetha School of Engineering, Saveetha University. The students were from private and government affiliated colleges located in Chennai, India. This survey was administered only to the willing participants and 360 filled-in questionnaire forms were chosen out of the total 400 responses. The questions were designed to find out the students' learning experience and the methodologies of English language teaching and how confident they felt about the enrichment of language skills required during interviews and group discussions. The participants were from different parts of India and different cultural backgrounds. The participants spent around 10 minutes on an average. In addition, the participants were asked to write down their comments about the English course in their own words so that they would be able to express their ideas which would help this study.

Table 1 illustrates the demographic information of the participants.

Table 1. Participants' demographic information (total number of participants: 360, nationality: Indians)

\begin{tabular}{lllll}
\hline Gender & \multirow{2}{*}{ Age Group } & $\begin{array}{l}\text { Qualification and number } \\
\text { of participants }\end{array}$ & Engineering Branches & States \\
\hline Male (85\%) & $18-24$ & B. Tech & Computer Science, EEE, & Tamilnadu, Gujarat, \\
Female (15\%) & & II Year (10.6) & ECE, Aerospace, Civil, & Andhra Pradesh, Jammu \\
& & IT, Mechanical Kashmir, & and \\
& & & $\begin{array}{l}\text { Bihar, Uttar Pradesh, } \\
\text { III Year (88.1\%) }\end{array}$ \\
& & & Delhi, West Bengal \\
\hline
\end{tabular}

Note: EEE-Electrical and Electronics Engineering. ECE-Electronics and Communication Engineering. IT-Information Technology.

During and after completion of the surveys, the researcher interviewed around 25 engineering students to understand their learning experience and the methodologies used. A full list of interview questions is available in Appendix A.

A pilot study was conducted to evaluate the quality of questions and semi-structured interviews questions to gauge the clarity of answers required for this study. The pilot study included ten fresh engineering graduates and necessary changes were incorporated according to the feedback received and expert review. The ten engineering graduates were not included in the formal study group.

\subsection{Data Analysis}

Data from the engineers was analyzed both quantitatively and qualitatively for the survey questionnaires. Data was extracted from the 360 questionnaires that were successfully filled and returned. The data has been presented in 
terms of percentage.

\section{Results}

\subsection{Engineering Students' Responses}

The following section offers findings from the survey questionnaires, followed by semi structured interviews and written feedback.

\subsection{Engineering Students Questionnaire-Survey I-Background}

The first part of the questionnaire focused on collecting the participants' backgrounds and demographics. All the participants belonged to 18-24 age group; the majority was male (85\%). They are from different states of India studying in Chennai, India in reputed institutes of technology.

\subsection{Questions 1 to 6-Learning Experience}

Questions 1 to 6 focused on the students' learning experience in their first year English classes and the purpose of these questions are to determine whether the students were able to enhance the language skills after two semesters of English courses offered in engineering colleges. Information was sought to understand whether the students felt confident to face job interviews and group discussions. It was found that many students needed to improve their language skills and they expected more effective and innovative methods of English language teaching. Table 2 explains the responses of engineering students.

Table 2. Responses of students about their learning experience

\begin{tabular}{|c|c|c|c|}
\hline Questionnaire Item & $\begin{array}{l}\text { Agree/Strongly } \\
\text { agree }(\%)\end{array}$ & $\begin{array}{l}\text { Disagree/Strongly } \\
\text { disagree }(\%)\end{array}$ & Indecisive $(\%)$ \\
\hline Learnt new language skills & 39.4 & 45.6 & 15 \\
\hline Confident to face job interviews & 17.5 & 58.7 & 23.8 \\
\hline Trained to participate in group discussion & 50 & 30 & 20 \\
\hline Improved my presentation skills & 29.3 & 43.2 & 27.5 \\
\hline $\begin{array}{l}\text { Got sufficient opportunities to practice language } \\
\text { and methodologies were student-centered. }\end{array}$ & 33 & 40.1 & 26.9 \\
\hline LSRW skills were sharpened & 37.5 & 38.1 & 24.4 \\
\hline
\end{tabular}

The significant factor of this survey is that more number of participants studied in English medium schools and was able to compare the syllabus and methodologies used in schools and their respective colleges.

\subsection{Questions 7 to 13-ELT Approaches and Methodologies}

After collecting the answers about their individual learning experience, the questions focused on how the students felt about the teaching methodologies and approaches. This was done to help students voice forth their honest judgment about the first year English course as students tended to give supportive views of their favorite professors in spite of reality. Analyzing their own language skills enhancement and evaluating their professors' methodologies stood apart as two different entities and the participants were able to give proper answers. Table 3 presents the details of responses about the methodologies used in the English classrooms.

Table 3. Responses about the methodologies used in the English classrooms

\begin{tabular}{llll}
\hline Questionnaire item & $\begin{array}{l}\text { Agree/Strongly } \\
\text { agree (\%) }\end{array}$ & $\begin{array}{l}\text { Disagree/Strongly } \\
\text { disagree (\%) }\end{array}$ & Indecisive (\%) \\
\hline $\begin{array}{l}\text { The methodology helped to understand real life } \\
\text { application of English language }\end{array}$ & 35.6 & 41.9 & 22.5 \\
Workplace language skills were taught & 40.6 & 36.2 & 23.2 \\
New teaching methodologies were used & 34.4 & 51.3 & 14.3 \\
Authentic evaluation methods of presentation skills & 30.6 & 45.7 & 23.7 \\
Updated workplace information was shared & 28.2 & 40 & 31.8 \\
$\begin{array}{l}\text { English sessions were different from engineering } \\
\text { teaching }\end{array}$ & 41.9 & 31.9 & 26.2 \\
\hline
\end{tabular}


These findings suggested that teaching methodologies implemented in engineering colleges needed to be transformed. When asked whether the students felt that the English course offered in first year served its purpose, $39.4 \%$ of respondents disagreed and $30 \%$ of students were indecisive. Figure 1 projects the results of final question whether the course served its purpose.

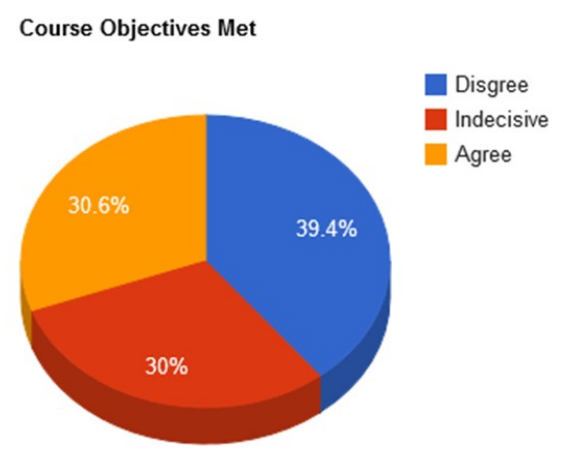

Figure 1. Overall effectiveness of English course as per students' responses

\subsection{Semi-Structured Interviews with Students}

The semi-structured interviews with the students contained a total of 9 questions and had 25 participants. Interviews took place in classrooms and the staff room in a conversational fashion to encourage students to articulate their opinions without inhibition. Interviews occurred during July to September 2014 and lasted an average of 15 minutes. Interview questions are available in Appendices B.

\subsubsection{Interview Questions 1-4}

The first four questions aimed at understanding the confidence levels of students in dealing with the challenges they have to face during group discussions and interviews. It was found that many students had little knowledge about group discussions and presentation skills as there was no proper feedback or training. Asked about group discussions in first year English classes, it was found that there was no formal group discussion and students were asked to form teams of 5 or 6 members and discuss a topic. After the discussions, which were not monitored by the teachers, one student from each group made a presentation to the whole class and the rest remained silent spectators. The silent ones were not encouraged to speak or given special attention.

\subsubsection{Interview Question 5}

Response to question number five indicate that the teachers spent more time teaching grammar i.e. tenses, voice, preposition etc. And the methodology of teaching grammar was quite mind-numbing and the students felt that they didn't learn anything new as they had studied grammar in their school education. After the teacher completed a topic, the students were asked to fill up the blanks in their workbooks. It was also found out that more number of students didn't participate in the learning process as many students felt the topics such as Tenses and active/passive voice were rudimentary. Moreover, many students felt that there wasn't much discussion about communication skills in the workplace except on the first day of class.

\subsubsection{Interview Questions 6-8}

The final section of questions revealed that the students studied English as a subject to score pass marks and there was no motivation among most of the students. Many said that their school syllabus was more challenging and interesting as they were encouraged to study novels, poems and plays; moreover, students of CBSE (Central Board of Secondary Education, India) informed that their school curriculum was far better as it encouraged creativity. They also cited that the number of students in each class was around 60 and some teachers found it very difficult to maintain order in the classrooms. These interview sessions with the third year engineering students suggested that the teaching methodology followed in colleges needed serious consideration and justified the poor show of students during campus placements and other job interviews. In addition, writing skills were not given more importance as a considerable number of students were found to be nervous about writing. Though letter writing is part of the English syllabus recommended in colleges, students informed that they learnt the sample letters given in their text books by heart and wrote them in their exams. It didn't encourage any creativity in writing.

Many students were not able to remember language activities conducted in their English classes and pointed out 
that most of the sessions were monotonous and mundane.

Table 4 shows the topics that are considered important by engineering students.

Table 4. Students' suggestions for first year English course in engineering colleges:

\begin{tabular}{|c|c|c|c|}
\hline Listening & Speaking & Reading & Writing \\
\hline Ability to collect & Simple Conversations & Passage comprehension & Creating documents such \\
\hline information & Telephone Etiquette & Interpreting charts, & as letters, directions, \\
\hline $\begin{array}{l}\text { Group Discussion } \\
\text { (Listening to } \\
\text { others) }\end{array}$ & Interpersonal Oral & $\begin{array}{l}\text { schedules and graphs } \\
\text { Critical } \quad \text { Reasoning } \\
\text { exercises }\end{array}$ & $\begin{array}{l}\text { manuals, reports, grapns, } \\
\text { and flow charts. } \\
\text { CV Writing }\end{array}$ \\
\hline Watching movies & Small formal presentations & Newspaper reading & Email Writing \\
\hline $\begin{array}{l}\text { Listening to videos } \\
\text { of } \\
\text { honchos }\end{array}$ & $\begin{array}{l}\text { Self-introduction } \\
\text { Job Interview Skills }\end{array}$ & $\begin{array}{l}\text { Short stories } \\
\text { Companies' websites } \\
\text { HR policies }\end{array}$ & Filling out forms \\
\hline
\end{tabular}

\subsection{Class Observation}

In order to confirm the survey results, the researcher observed the teaching methodology followed in some of the first year engineering classes. The names of the institutions and teachers have been withheld to protect identities. During these sessions, four faculty members were found to be spending more time on teaching grammar i.e. Tenses, Active and Passive Voice, kinds of adjectives etc. Although grammar instruction has recently been associated with contextual teaching (Clandfield, nd; Tennant, nd), this practice hasn't yet taken root in engineering colleges in India. Moreover, the sessions were found to be more teacher-oriented and there was less participation from students. Many students were found to be indifferent as the focus was more on filling up the answers in the recommended workbooks. This monotonous approach of reading and answering questions seemed to have stolen the enthusiasm from the learners. According to Bayram Pekoz (2008), the teacher should bring grammar instruction to life, stimulate interest in the topic, and raise awareness by providing a reason for learning. Moreover, the workbooks were found to be the compilation of past question papers of university exams without much content related to English for employability. The exercises given were not stimulating to the minds of young learners in first year without any interesting activities.

In another session, the teacher was found to be extremely good at speaking and was lively. And the students were found to be responding to the teacher enthusiastically. A few students who were good at speaking engaged the teacher in discussion and asked further questions whereas the majority of the students were listening quietly without any direct interaction with the teacher. Though the class was interesting to follow, it was the teacher who dominated the whole process which nullified the student-centered approach. The researcher observed a presentation session in which the first year students made individual presentations on topics of their choice. There were around fifteen presentations made during that session and there were good, average and bad presentations. The teacher found it difficult to motivate many students to deliver presentations as many students felt shy to speak in front of their classmates. The teacher offered some feedback to some of the students but there was no evaluation procedure to assess the performance of the students in terms of language accuracy, sentence structure, intonation, gestures etc. This corroborates the survey result that students felt that they didn't feel confident about their presentation skills. Marks were awarded arbitrarily and many students didn't show any interest in asking suggestions for improvement which is mandatory to identifying areas of improvement. It was also found that there was no lecture session on the techniques of effective presentations by the teacher prior to the session and hence most students made presentations as per their own assumptions without any uniformity. Lack of motivation among students dampen the spirits of English professors and according to Dr. Bayram N. PEKÖZ (2009) teachers ought to mull over students' inclination, likes and desires in selecting suitable motivator.

Moreover, though the objectives of English syllabus recommended by government and private universities to train the learners to develop basic communication skills and to inculcate the habit of reading and writing, it was observed that the teaching-learning process followed in first year English classes needed a thorough makeover and many teachers needed ESP training to train the engineering students for employability. These findings corroborate with the recommendation of Paul Spence that English courses need to incorporate English communicative events within a syllabus to bridge the gap between the university and the workplace (Spence \& Liu, 2013). 


\section{Written Comments of Engineering Students}

Students were asked to write down their feedback on effectiveness of first year English program as some students were not comfortable talking. Writing down their assessment and expectations gave them the necessary freedom to think freely without any inhibitions. Their comments have been presented below:

"Teachers must be more interactive in classes. They must focus more on boosting communication skills. My professor was more interested in completing the syllabus than training us".

"English faculty must introduce new techniques to make the sessions interesting. They must pay individual attention to all students. English faculty must deal with students' inhibitions. Modern methods of presentation must be given importance. English must be taught with real life examples to create more interest in learning process".

"Interview and group discussion training must start from the very first year of engineering courses so that students will have time to correct their errors. The standard of English course in first year did not meet the standard of English language taught in higher secondary education. Moreover, the English course in college was not relevant to our needs in future".

"Teaching methods were not good and teachers must be evaluated from time to time. Instead of syllabus oriented teaching, English professors must concentrate on activity oriented teaching. Professors must share practical knowledge of presentation skills".

"We need more opportunities to interact than just listening to lectures. Professors must help us to overcome stage fright. Our first year English classes were focused on grammar. It must be more interactive sessions. Professional conversations and business letters must be taught. Presentation skills in workplace and meetings must be emphasized during English classes".

"Professors must share updated information about companies. The English course in first year was the same as school English course. The evaluation methods were poorer. The exercises deployed to increase writing skills could have been better. For inculcating professional writing ethics, students should be given a project for developing content for an organization that is seeking to market or employ new ideas for products".

"English theory/paper test must be scrapped and more evaluation activities must be introduced to improve communication skills. Serious introspection is expected to revamp the first year English classes. SWOT analysis of communication skills must be conducted by English faculty. Book reading and talking must be encouraged".

"My professor didn't tell me why I was given marks for my presentation. He must have told me the areas of improvement and my strengths".

"Written exams must be abolished for English courses. More innovation is required in the methodology for creating enthusiasm".

"Newspaper reading and discussions on current affairs must be introduced".

"School syllabus involves a lot of stories, plays and poems which helped us improve our vocabulary and language skills. On the contrary, college English course was all about grammar".

The written comments of students call for more systematic ELT methodologies in engineering classrooms. These comments have stressed the need for equipping English professors in methodologies of English for Specific Purposes. English teachers in engineering colleges must be exposed to English for employability and its methodologies.

\section{Discussions}

Engineering students are faced with challenging and demanding recruitment process in which they have to prove their mettle with English communication skills. Besides being good at English, they need to be aware of the employability skills required at their future workplaces. The ability to listen, question and express opinions and ideas properly and produce written work that is lucid, clear and structured using correct spelling and grammar has become mandatory for every engineering student (The UK Commission for Employment and Skills (2009). In addition, they require exemplary English skills in listening, speaking, reading, and writing to go up the career ladder. The big question is whether the engineering students are aptly trained in their colleges to face the challenges.

Our findings indicated that there have been huge gaps in English language teaching practices followed in engineering colleges in India. Many teachers seem to have a little or no knowledge about ESP or English for Employability. The students were not adequately trained to face the recruitment process of multinational 
companies in India. The engineering students felt that the English classes needed to be different from engineering subjects and teachers needed to conduct more activities which would encourage interaction in the classroom instead of the passive teaching methodology such as teacher-centered curriculum, passive role of learners (Chao-ching Lin, 2002). This implies that engineering English should include more interactive sessions and language activities that would strengthen and sharpen communication skills of students as effective classroom interactive sessions help the learners to become effective communicators (Mateja Dagarin 2004). More specifically, the English professors need to be trained in Communicative Language Teaching and get exposed to the challenges faced by professionals in various industries. Mere changes in the syllabus will not be able to bring in desired changes unless the English teachers are motivated to enhance their teaching methodologies to bridge the gap between the college and the workplace. Additionally, teaching English grammar without context doesn't seem to help the engineering students to understand the effectiveness of grammatical structures. The teacher must bring grammar teaching to life, arouse interest in the theme, and raise consciousness by providing a motive for learning and offer an occasion to put grammar instruction to real life situations (Bayram Pekoz,2008). Efforts must be taken to use grammar in workplace situations to create interest in the minds of the learners so that the importance of learning grammar is emphasized. Needs assessment is mandatory in ESP (English for Specific purposes) to understand the needs and expectations of the learners to create a meaningful learning environment as the objective of English courses is to enhance employability skills.

To create awareness about the importance of language skills in job interviews and workplace activities, the English teachers need to provide a lot of information from newspaper articles and websites. As students want to learn more about employability, it has become obligatory for the teachers to read and share facts about language proficiency required by companies. As many students feel less confident about their presentation skills, novel methods of training must be introduced in classes to boost self-confidence. Videos of great speakers and leaders along with structured training sessions will surely equip the engineering graduates to share their views effectively and convincingly. More specifically, care must be taken to encourage students with low self confidence and colleges must arrange separate training sessions as weak students may feel inferior in front of their counterparts who are proficient in English language skills. According to Nation (2000), teachers can create experience- sharing opportunities for students to make use of their experience in doing the assignment. Teachers must teach oral skills and strategies while preparing students for communication activities. Also, it is desirable that teachers rate the difficulty level of oral tasks to suit their students' ability to communicate. If easy activities with clear instructions are introduced in the class, students will feel comfortable exercising their skills with ease and the difficulty level can be increased as the students' confidence level enhances. Many students felt that evaluation based on theory papers must be scrapped and students must be continuously assessed on communication activities such as individual presentations and group discussions. The board of studies, English professors and industry professionals must come together to prepare a syllabus that will suit the current needs of the industry and a training program for English professors to upgrade and change their focus to English for employability. Though many teachers understood the importance of communicative competence, the limitations of classroom reality block them from implementing their ideas (Jihyeon Jeon, 2009).

Activities such as official email communication, teleconference, project proposals, memos, minutes of meeting and oral presentations must be introduced. Further, since engineers are required to communicate with international clients, they must be trained to understand various accents of English. Besides these activities, students must be encouraged to read newspapers in classrooms to learn vocabulary and to improve their reading skills. Newspaper reading will surely help the students to understand the world and the needs of employability skills. ELT experts must help English professors in engineering colleges to transform the teaching methods for bridging the gap between the colleges and the industry so that the employability barrier can be shattered to pieces for the benefit of engineering graduates in Indian engineering colleges.

\section{Conclusions}

This study examined the English language skills required by the engineering students studying in India and the gap between the teaching methodology and the harsh reality of students' language skills. The findings pointed to the big gap between the teaching methodologies and the confidence levels of engineering students and how this scenario affects the employment opportunities of thousands of engineering students in India. In addition, the study revealed the training need for English professors to train the engineering students for employability. The findings in this study expose the necessity for meticulous professional development programs for English professors working in engineering colleges. Moreover, the teachers must work closely with the students to understand their needs and chart out an effective methodology for training them. The professors must go beyond textbooks and break the barriers of teaching process. If the English professors are exposed to the reality of industry challenges, 
the gap between the student engineer's academic environment and workplace could be reduced and the employability skills of students will be enhanced.

\section{Limitations and Scope of the Study}

This investigation was conducted to unravel the need for streamlining the English language training in engineering colleges of India. This study was conducted in Chennai which is one of the four biggest cities in India. The aspects looked into were the qualifications of teachers, their methods and strategies, the students' feedback, problems and proposed solutions to problems. Though the results of this work reflect the overall ELT situation in the engineering colleges, institutions situated in rural areas face serious setbacks as educational systems in some of the states need to be improved and students in those institutions require more intensive training. Hence, further investigations must be conducted among the rural students to find out the suitable solutions for the challenges.

\section{References}

Acharjee, S. (2013). Emerging colleges 2013: How small town India is catching up with the metros: NATION. India Today. Retrieved from http://indiatoday.intoday.in/story/india-today-best-emerging-colleges-2013/1/ 280171.html

Aspiring Minds. (2014). National employability report - Engineers. Annual report-2014 (pp. 1-63).

Blom, A., \& Saeki, H. (2011). Employability and skill set of newly graduated engineers in India. Policy research working paper (p. 5640). World Bank, Washington DC 1-33.

Cassidy, S. (2006). Developing employability skills: Peer assessment in higher education. Journal of education and training, 48(7), 508-517. http://dx.doi.org/10.1108/00400910610705890

Cassidy, S. (2006). Learning style and student self-assessment skills. Journal of education and training, 48(2/3), 170-177. http://dx.doi.org/10.1108/00400910610651791

Clandfield, L. (n.d.). Task-based grammar teaching. Onestopenglish. Retrieved October 4, 2014, from http://www.onestopenglish.com/grammar/grammar-teaching/task-based-grammar-teaching/

Dagarin, M. (2004). Classroom interaction and communication strategies in learning English as a foreign language - English language overseas perspectives and enquiries: Studies in the English language and literature in Slovenia. Slovene association for the study of English.

Ferrari, A., \& Dhingra, I. (2009). India's investment climate: Voices of Indian business. Washington, DC: World Bank publications.

Graddol, D. (2010). English Next, India. New Delhi: British Council.

Jihyeon, J. (2009). Key issues in applying the communicative approach in Korea: Follow up after 12 years of implementation. English teaching, 64(4), 123-150. http://dx.doi.org/10.15858/engtea.64.4.200912.123

Lin, C. (2001). Personalizing language learning in large classes (TESL/TEFL). Retrieved October 4, 2014, from http://iteslj.org/Articles/Lin-Personalizing.html

Mehtabul, A., Chin, A., \& Prakash, N. (2010). The returns to English-language skills in India. CReAM discussion paper series 1002, Centre for Research and Analysis of Migration (CReAM), Department of Economics. UK: University College London.

NASSCOM and McKinsey. (2005). NASSCOM and McKinsey Report 2005: Extending India's leadership of the global IT and BPO industries. India: NASSCOM and McKinsey, New Delhi.

Nation, I. S. P. (2000). Creating, adapting and using language teaching techniques. English Language Institute Occasional Publication No. 20. Victoria University of Wellington.

P'Rayan, A. ( 2011). Engineering English: A critical evaluation. Language in India, 11(12), 10-283.

P'Rayan, A. (2007). Role play games in the English class. Education Express, The New Indian Express.

Padwad, A., \& Dixit, K. (2011). Continuing Professional Development: An Annotated Bibliography. Kolkata: British Council.

Pandey, M., \& Pandey, P. (2014). Better English for better employment opportunities. International journal of multidisciplinary approach and studies, 1(4), 93.

Pekoz, B. (2008). Integrating grammar for communicative language teaching. The Internet TESL journal, $X I V(10)$. Retrieved from http://iteslj.org/Techniques/Pekoz-Grammar.html 
Pekoz, B. N. (2009). Teaching language skills (p. 7). Ankara: Ani Publishing.

Pereira, P., Louis, A., \& Lok, H. (2002). Employers' perspective of English language needs of BBA graduates. IRDC research. UiTM.

Riemer, M. J. (2002). English and communication skills for the global engineer. Global J. of Engng. Educ, 6(1), 91.

Seetha, S. (2012). Communication skills for engineers in global arena. International journal on arts, management and humanities, 1(1), 1-6.

Spence, P., \& Liu, G. (2013). Engineering English and the high-tech industry: A case study of an English needs analysis of process integration engineers at a semiconductor manufacturing company in Taiwan. English for specific purposes, 32(2), 97-109. http://dx.doi.org/10.1016/j.esp.2012.11.003

Tennant, A. (n.d). The discovery technique. Onestopenglish. Retrieved from http://www.onestopenglish.com/ grammar/grammar-teaching/the-discovery-technique/

UKCES. (2009). The employability challenge. London: UK Commission for Employment and Skills. http://www.ukces.org.uk/upload/pdf/EmployabilityChallengeFullReport.pdf

\section{Appendix A. Questionnaire Survey}

1) I learned new language skills in my first year English classes.

2) I feel confident to face my interview due to the English training offered to me in first year.

3) I was trained to participate in group discussions without inhibitions.

4) My presentation skills were improved due to the methodology followed in English classes.

5) English classes were student-centered and I got many opportunities to practice my language.

6) My LSRW skills were sharpened after the first year course.

7) My English faculty helped me understand the real life applications of English language.

8) My English professor taught me the language skills I require in my workplace.

9) My professor introduced new teaching techniques to make the sessions interesting.

10) Due to my professor's authentic evaluation methods, I understood my weaknesses and strengths of my presentation and group discussion skills.

11) My professor was able to share a lot of updated information about the workplace scenario.

12) English sessions were different from engineering sessions.

13) Course objectives were accomplished.

\section{Appendix B. Students Semi-Structured Interview Questions}

1) How comfortable are you with English language skills to deal with your interviews and group discussions?

2) Are you confident to answer questions during interviews?

3) Are you comfortable to make presentation in front of your class after completing your I year English course?

4) Were you trained well for speaking confidently in English in I year?

5) Did you learn anything new about English grammar and its context applications?

6) How useful was the first year English course?

7) Are you good at writing in English?

8) How many activities were conducted in your English sessions to encourage students' participation?

9) In which areas would you like to be trained?

\section{Copyrights}

Copyright for this article is retained by the author(s), with first publication rights granted to the journal.

This is an open-access article distributed under the terms and conditions of the Creative Commons Attribution license (http://creativecommons.org/licenses/by/3.0/). 